\title{
Myotonic Dystrophies: Targeting Therapies for Multisystem Disease
}

\author{
Samantha LoRusso ${ }^{1} \cdot$ Benjamin Weiner ${ }^{2} \cdot$ W. David Arnold ${ }^{1}$ \\ Published online: 18 October 2018 \\ (C) The American Society for Experimental NeuroTherapeutics, Inc. 2018
}

\begin{abstract}
Myotonic dystrophy is an autosomal dominant muscular dystrophy not only associated with muscle weakness, atrophy, and myotonia but also prominent multisystem involvement. There are 2 similar, but distinct, forms of myotonic dystrophy; type 1 is caused by a CTG repeat expansion in the $D M P K$ gene, and type 2 is caused by a CCTG repeat expansion in the CNBP gene. Type 1 is associated with distal limb, neck flexor, and bulbar weakness and results in different phenotypic subtypes with variable onset from congenital to very late-onset as well as variable signs and symptoms. The classically described adult-onset form is the most common. In contrast, myotonic dystrophy type 2 is adult-onset or late-onset, has proximal predominant muscle weakness, and generally has less severe multisystem involvement. In both forms of myotonic dystrophy, the best characterized disease mechanism is a RNA toxic gain-of-function during which RNA repeats form nuclear foci resulting in sequestration of RNA-binding proteins and, therefore, dysregulated splicing of premessenger RNA. There are currently no disease-modifying therapies, but clinical surveillance, preventative measures, and supportive treatments are used to reduce the impact of muscular impairment and other systemic involvement including cataracts, cardiac conduction abnormalities, fatigue, central nervous system dysfunction, respiratory weakness, dysphagia, and endocrine dysfunction. Exciting preclinical progress has been made in identifying a number of potential strategies including genome editing, small molecule therapeutics, and antisense oligonucleotide-based therapies to target the pathogenesis of type 1 and type 2 myotonic dystrophies at the DNA, RNA, or downstream target level.
\end{abstract}

Key Words Myotonic dystrophy $\cdot$ myopathies $\cdot$ biomarker $\cdot$ splicing $\cdot$ therapeutic.

\section{Introduction}

The myotonic dystrophies are autosomal dominant skeletal muscle disorders associated with multisystem involvement. Myotonic dystrophy type 1 (DM1; OMIM \#160900) is the most common form of muscular dystrophy in adulthood, affecting about 1 in 8000 individuals; however, reported prevalence varies significantly depending on the population studied $[1,2]$. DM1 is caused by a cytosine, thymine, guanine (CTG) repeat expansion of $>50$ repeats in the dystrophia myotonica protein kinase $(D M P K)$ gene on chromosome 19q13.3.

Electronic supplementary material The online version of this article (https://doi.org/10.1007/s13311-018-00679-z) contains supplementary material, which is available to authorized users.

W. David Arnold

William.arnold@osumc.edu

1 Department of Neurology, The Ohio State University, 395 West 12th Avenue, Columbus, OH 43210, USA

2 The Ohio State University College of Medicine, The Ohio State University, 370 West 9th Avenue, Columbus, OH 43210, USA
Myotonic dystrophy type 2 (DM2; \#602668) is a phenotypically similar but distinct disorder related to a CCTG repeat expansion in the CCHC-type zinc finger nucleic acidbinding protein (CNBP, also known as ZNF9) gene on chromosome 3q21 [3].

There are currently no disease-modifying treatments available for the myotonic dystrophies. The systemic nature of these disorders has significant implications outside of the muscular system (Fig. 1), and in many individuals, extramuscle involvement far exceeds skeletal muscle impairment. In this review, we will discuss the multisystem symptom burden of DM1 and DM2, the recent progress in the understanding of molecular pathogenesis, and how this understanding is leading to the development of potential strategies for therapeutic intervention.

\section{Overview}

DM1 shows a remarkably diverse set of symptoms and wide variability of disease onset, and together, this often results in a 
Fig. 1 Multisystem effects of myotonic dystrophy

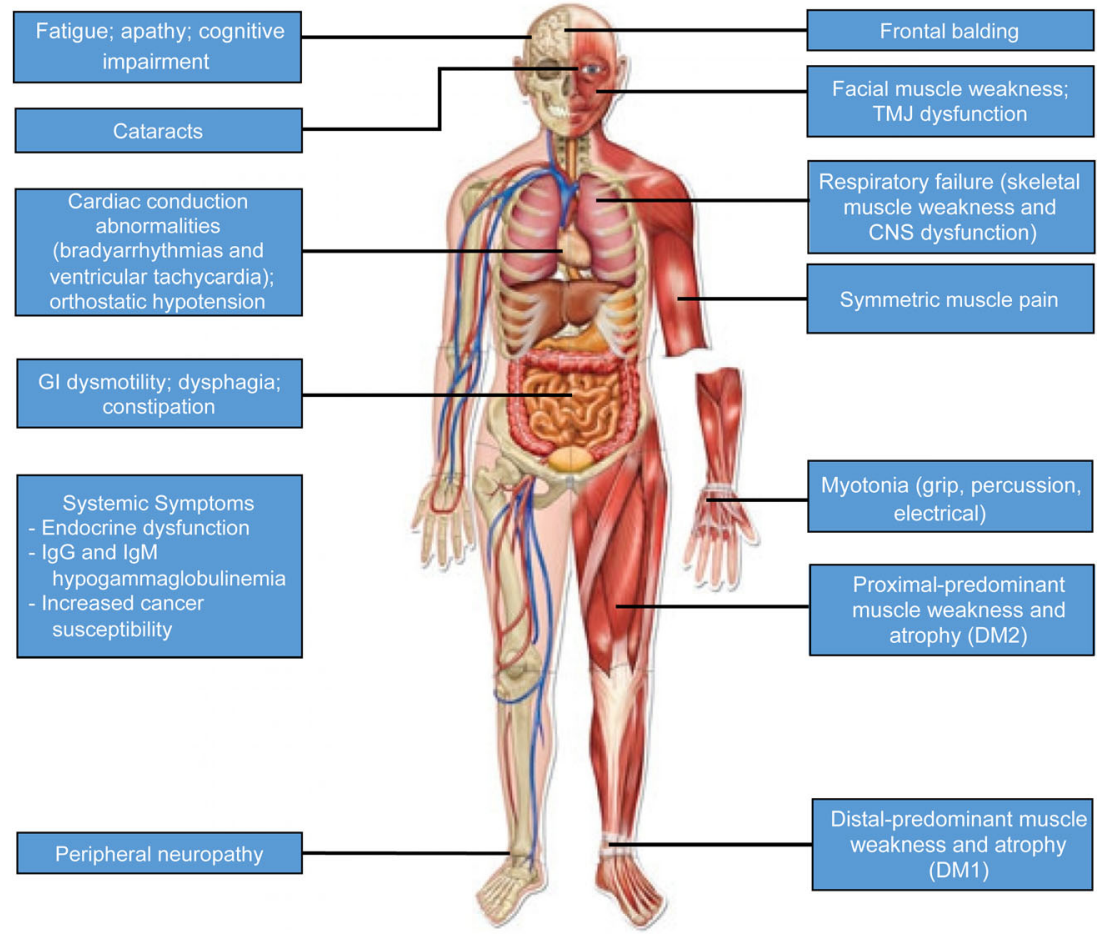

delay in diagnosis or misdiagnosis [4]. DM1 has traditionally been broadly divided into 3 phenotypic groups: congenital, classic, and mild. These phenotypic groups have been further subdivided into congenital, childhood-onset, adult-onset, lateonset, and premutation subtypes with some authors also including a juvenile-onset subtype (Table 1) [5, 6]. The classically described and best characterized subtype is adult-onset DM1, with wide-ranging variability in its prevalence, between 0.5 and 18.1 per 100,000 [7]. It also exhibits a significant founder effect; for example, its frequency is 1 in 550 in Northeastern Quebec [8]. Adult-onset DM1 is associated with cataracts, abnormal muscle relaxation related to myotonia, muscle weakness and atrophy, cardiac conduction abnormalities, central nervous system (CNS) dysfunction, sleep disorders, gastrointestinal and endocrine dysfunction, frontal balding, and shortened lifespan [8, 9]. Congenital DM1, occurs at a frequency of about 2 per 100,000 and is characterized by hypotonia at birth with the absence of myotonia, significant intellectual impairment, and a high frequency of respiratory insufficiency or failure leading to death in about $30 \%$ in the neonatal period $[10,11]$. Both childhood-onset and juvenile forms are characterized by cognitive dysfunction, particularly

Table 1 Characteristics and subtypes of the myotonic dystrophies (table modified from De Antonio et al. [5] and Ho et al. [6])

\begin{tabular}{|c|c|c|c|c|c|}
\hline & \multicolumn{2}{|c|}{ Subtypes } & Age of onset & Prominent findings at clinical diagnosis & Repeat size \\
\hline \multirow[t]{6}{*}{ Type 1} & \multicolumn{2}{|c|}{ Congenital } & Apparent at birth & $\begin{array}{l}\text { Hypotonia, respiratory insufficiency/failure, } \\
\text { cognitive impairment }\end{array}$ & $>1000-2000$ \\
\hline & \multirow[t]{4}{*}{ Classic } & Childhood-onset & $<10$ years & $\begin{array}{l}\text { Cognitive impairment leading to psychosocial } \\
\text { issues, muscle weakness, myotonia, cataracts, } \\
\text { cardiac conduction abnormalities, incontinence }\end{array}$ & $50-1000$ \\
\hline & & Juvenile-onset & $10-20$ & $\begin{array}{l}\text { Cognitive impairment including psychosocial } \\
\text { problems; weakness and cardiac symptoms } \\
\text { may be absent at first }\end{array}$ & $50-1000$ \\
\hline & & Adult-onset & $20-40$ & $\begin{array}{l}\text { Myotonia, weakness, cardiac conduction } \\
\text { abnormalities, GI dysmotility, milder cognitive } \\
\text { impairment, endocrine abnormalities }\end{array}$ & $50-1000$ \\
\hline & & Late onset & $>40$ & $\begin{array}{l}\text { Myotonia, cataracts, mild weakness, aging-related } \\
\text { cognitive decline }\end{array}$ & $50-100$ \\
\hline & \multicolumn{2}{|c|}{ Premutation } & Asymptomatic & None & $38-49$ \\
\hline \multicolumn{3}{|l|}{ Type 2} & $8-60$ & $\begin{array}{l}\text { Proximal weakness, myotonia, myalgia, tremor, } \\
\text { less prominent involvement of other systems }\end{array}$ & 75-11,000 (average 5000) \\
\hline
\end{tabular}


psychosocial impairment; however, the juvenile form typically has fewer motor and cardiac symptoms than the childhoodonset form until later in life. Late-onset DM1 is characterized by cataracts, less severe muscle involvement, and normal lifespan. Individuals with premutations, CTG repeat size from 38 to 49 , are asymptomatic but are at increased risk of transmitting a pathologically expanded mutant allele. It has been suggested that disease phenotype is more severe in males with DM1 [12].

Although there are many overlapping phenotypic features in DM1 and DM2, key characteristics that distinguish DM2 from DM1 include a more proximal pattern of muscle weakness and overall less severe cardiac, respiratory, and central nervous system involvement [13]. In contrast to DM1, onset of DM2 occurs in adult ages with no reports of congenital onset (Table 1). Multisystemic features are not as prominent in DM2, but earlier onset disease is associated with more prominent multisystemic involvement [14]. Symptoms of DM2 appear to be sexually dimorphic, as women more frequently show proximal muscle weakness and more severe disease, whereas men more frequently show symptoms of myalgia-type pain [14]. DM2 is less common than DM1, with a reported prevalence of 0.99 per 100,000 [7].

\section{Multisystem Symptom Burden and Overview of Clinical Care}

\section{Skeletal Muscle}

The most prominent features of the myotonic dystrophies are skeletal muscle weakness, atrophy, and myotonia. The pattern of muscle weakness significantly differs between DM1 and DM2. DM1 typically presents in a predominantly distal pattern, with certain muscle groups such as long finger flexors, ankle plantar flexors, and ankle dorsiflexors being more severely affected. Jaw and facial muscles, as well as the neck flexors, are also significantly involved. In contrast, DM2 presents in a proximal predominant pattern. Facial and bulbar muscles are spared in the majority of DM2 patients. In both DM1 and DM2, symptoms of weakness are typically symmetric. Muscle pain is common in both DM1 and DM2, being reported in about 50 to $90 \%$ of patients, but may be more overlooked in DM1 because of the emphasis on other symptoms by patients and physicians $[15,16]$. In DM2, pain is the first symptom of disease in up to $11 \%$ of patients [4].

There are currently no treatments for muscle weakness other than supportive interventions. Exercise appears to be safe and well tolerated, but study results have been mixed in regard to improvement of function [17-20]. Distal leg weakness, more prominent in DM1, can result in significant gait difficulties. Ankle foot orthoses, such as off-the-shelf anterior shell carbon fiber ankle-foot orthoses (ground reaction ankle foot orthoses), can be helpful to increase stride length and improve gait mechanics and are well tolerated by patients [21]. Ground reaction ankle foot orthoses, in addition to helping with plantarflexion and dorsiflexion weakness, may also help with knee extension weakness, a common feature in DM1.

Clinical and electrical myotonia is almost always present in patients with adult-onset DM1 and has been shown to correlate with CTG repeat size [22]. Myotonia may occasionally cause severe impairment of limb or bulbar function (speech or swallowing) in patients with DM1, but this is rare in DM2 [13]. In DM2, clinical myotonia is present in less than 50\% of patients and electrical myotonia is variable and can be difficult to elicit $[13,23]$. However, modifier genes, specifically $S C N 4 A$ and $C L C N 1$, can change the severity of myotonia in DM2. Cases of both $C L C N 1$ and $S C N 4 A$ mutations present in DM2 patients have been shown to enhance the myotonic phenotype [24-26]. Sodium channel blockers, such as mexiletine, have been used for many years to treat myotonia in both the myotonic dystrophies as well as the nondystrophic myotonias. A randomized, double-blind, placebo-controlled trial did show it to be effective in reducing clinical myotonia in patients with DM1 without any significant adverse events [27]. However, the drug does have proarrhythmic potential, and use is contraindicated in second- or third-degree AV block which may increase risk in some patients with DM. Lamotrigine, another sodium channel blocker, has been shown to be effective in nondystrophic myotonia, and ranolazine, which increases slow inactivation of sodium channels, may be effective for the treatment of myotonic dystrophy as well as nondystrophic forms of myotonia such as paramyotonia congenita and myotonia congenita [28-32].

\section{Other Neurological Manifestations}

An array of both peripheral nervous system and CNS abnormalities have been reported in both DM1 and DM2. The manifestations of CNS impairment in the myotonic dystrophies may be 1 of the most important yet poorly understood aspects of the disease and were recently reviewed in detail by Gourdon and Meola [33]. Commonly reported CNS-related symptoms include fatigue, apathy, and cognitive difficulties. Although it has been suggested that fatigue may be related to the sleep-disordered breathing observed in this population, some studies have shown no relationship [34]. Symptoms of fatigue are likely multifactorial and may be related to peripheral and central factors. Individual-reported severity of fatigue as measured by the Fatigue Severity Scale has been shown to correlate with muscle function [35]. Impaired muscle activation was reported over 30 years ago in myotonic dystrophy, and this could reflect factors such as impaired motor unit recruitment or rate coding, which could influence fatigue as well as muscle function [36]. 
Modafinil has long been used for the treatment of hypersomnia and fatigue in myotonic dystrophy. A Cochrane review in 2006 examined the use of psychostimulants in DM and found that only 4 studies showed modafinil to have slight, but inconsistent benefits [37]. A double-blind, placebo-controlled trial in 13 patients performed later showed that modafinil did reduce somnolence but did not significantly increase activity level [38]. Still, a large survey including 145 patients with DM1 and 146 relatives found that $85 \%$ of responders believed modafinil had been of "marked or dramatic" benefit [39].

Cognitive impairment and fatigue have been associated with worse quality of life measures in adult patients [40]. One study comparing cognitive dysfunction in DM1 and DM2 showed that almost all DM1 patients had deficits in multiple cognitive domains whereas $1 / 3$ of DM2 patients had completely normal findings [41]. In this study, the most commonly affected domains in both DM1 and DM2 patients were visuospatial and executive function. In DM1, cognitive problems are broadly associated with CTG repeat size as congenital forms have severe cognitive delay, whereas those with a mild phenotype seem to perform better on cognitive measures than those with a classic adult-onset phenotype [42]. There is significant variability, however, which is likely due to the differences in repeat size between tissues [43].

Peripheral neuropathy has been reported in both DM1 and DM2 and appears to occur in about 10 to $15 \%$ of patients on the basis of nerve conduction studies, but clinical symptoms related to neuropathy such as loss of balance or sensory loss are not usually evident $[44,45]$. Potential autonomic manifestations of peripheral nervous system involvement could include some of those discussed as part of the cardiac and GI symptom burden (i.e., cardiac conduction abnormalities, orthostatic hypotension, GI dysmotility), but it has been argued that these are primarily due to target organ involvement rather than generalized autonomic system involvement [46].

\section{Respiratory}

Respiratory failure is the most common cause of death in myotonic dystrophy [47]. It has been correlated with CTG repeat size and may even exist in the absence of significant muscle weakness [48]. The respiratory dysfunction likely results from a combination of skeletal muscle weakness and central nervous system dysfunction $[49,50]$. Irregular breathing patterns, sleep breathing disorders, and the finding of reduced ventilatory response to $\mathrm{CO}_{2}$ independent of respiratory muscle weakness all suggest that the central nervous system plays an important role in pathogenesis [50-52]. Importantly, it has been noted that patients with DM1 may not be aware of their symptoms related to respiratory failure so physicians should be careful in the way questions are posed and monitor respiratory parameters even in the absence of obvious symptomatology [49]. Although respiratory parameters are typically monitored upright, supine evaluation of pulmonary function may be more sensitive at detecting a restrictive ventilatory pattern [48]. With regard to supportive care, noninvasive ventilation for respiratory weakness has been shown to potentially improve survival in DM1 patients, but therapeutic adherence may be poor and requires close follow-up [53]. This is being explored further in an ongoing open label, multicenter randomized controlled trial assessing the utility of early nocturnal noninvasive ventilation versus annual monitoring (DYVINE; NCT01225614).

\section{Cardiac}

Cardiac involvement in myotonic dystrophy was noted in 1911 shortly after the original description of the disease [54]. In contrast to other myopathies and dystrophies, cardiomyopathy is less common (though it does occur), but cardiac conduction abnormalities occur in a majority of patients with DM1 [55]. In DM1, cardiac conduction abnormalities range from asymptomatic PR interval prolongation to complete heart block and correlate with repeat expansion size [56-58]. Progression of cardiac conduction abnormalities is usually slow but is variable and can be unpredictable presenting a challenge for surveillance and management $[59,60]$. Cardiac-related involvement is the second most common source of mortality in DM1, resulting in about 30\% [47] of deaths. Bradyarrhythmias and ventricular tachycardia are likely the primary sources of sudden death, but ventricular dysfunction is also a contributor, albeit much less commonly [61-63]. Pathological analyses of postmortem tissues have shown degeneration, fibrosis, and fatty infiltration of the conduction system, typically the His-Purkinje system but also in the sino-atrial and atrioventricular nodes, and this can result in ectopic activity, conduction failure, and arrhythmias [61, 64-66].

In contrast to DM1, the frequency and severity of involvement of the cardiac system are less in DM2 [67]. In an observational study of $104 \mathrm{DM} 2$ and 117 DM1 patients, the PR interval and QRS interval were significantly longer in the DM1 cohort, and the frequency of PR prolongation $(\geq$ $200 \mathrm{~ms}$ ) was $17 \%$ in DM2 as compared with $31 \%$ in DM1 [67]. Despite the reduced frequency of cardiac involvement in DM2, $6 \%$ of DM2 patients in this study required pacemaker or defibrillator implantation [67]. Another interesting point noted in this study is that conduction deficits in DM1, but not DM2, were significantly correlated with age [67].

Management of cardiac involvement involves surveillance and prophylactic treatment with pacemaker and defibrillator implantation. Initial recommended screening evaluation includes electrocardiography, echocardiogram, and Holter monitor [63]. Conduction disease on electrocardiography and history of atrial fibrillation are known predictors of sudden death 
[68]. Implantation of pacemakers is indicated for patients with symptomatic type II and complete atrioventricular block or bradycardia, and defibrillator implantation should be considered for documented sustained ventricular tachycardia, similar to patients without neuromuscular disorders. The unpredictability of progression of conduction disease and the discordance that can occur between symptoms of weakness and cardiac conduction abnormalities necessitates a lower threshold for considering intervention [69]. Prophylactic invasive investigation and preventative measures appear to improve survival in DM1 patients [70].

\section{Gastrointestinal}

Gastrointestinal manifestations are frequent in the myotonic dystrophies, with dysphagia being the most common gastrointestinal complaint in DM1 and constipation the most common in DM2 [71]. Other reported symptoms include acid reflux, fluctuations between diarrhea and constipation that may mirror irritable bowel syndrome, gallbladder problems with a high frequency of cholecystectomy, and liver problems [71]. Pseudo-obstruction of the small bowel, as well as lower GI tract problems such as fecal incontinence, has also been reported [72-74]. The pathogenesis of GI symptoms remains to be fully ascertained. GI involvement is correlated with the duration of disease but not the severity of skeletal muscle involvement in DM1 [75]. One small study did show a correlation between CTG repeat size and GI symptoms of dysphagia, abdominal pain, and constipation, but larger studies have not $[71,76]$. The treatment of dysphagia is supportive, and no clear guidelines exist for its management. Other gastrointestinal symptoms are treated with antacid medications, prokinetic agents, laxatives, and cholecystectomy although again, clear guidelines are lacking $[71,75]$. For symptoms of small intestinal bacterial overgrowth, treatment with antibiotics, such as ciprofloxacin, may be effective [77].

\section{Other Systemic Involvement}

A number of other multisystem features of myotonic dystrophy are also common, including ophthalmologic, endocrine, immune, sleep, and dermatologic effects, among others. Cataracts are a characteristic feature of myotonic dystrophy, are present in most patients with DM1 and the majority of patients with DM2, and may be a diagnostic clue for the astute practitioner [13, 78]. Asymptomatic immunoglobulin $\mathrm{M}$ and immunoglobulin $\mathrm{G}$ hypogammaglobulinemia are present in a majority of patients with both DM1 and DM2 but have not been associated with any important clinical implications [79, 80]. About a 2-fold increased cancer susceptibility has been reported in myotonic dystrophy with endometrial, brain, ovarian, and colon cancers carrying the highest risk compared to the general population [81]. Endocrine dysfunction may include primary hypogonadism, hyperinsulinism usually without frank diabetes and likely related to insulin resistance, and frontal balding, apparent in at least half of patients and increases during aging [82].

\section{Molecular Pathophysiology}

\section{DM1}

DM1 results from an unstable expansion of a CTG repeat in the $3^{\prime}$ untranslated region of the DMPK gene, and disease transmission is autosomal dominant with variable penetrance [83]. Affected individuals, homozygous for mutant expansion repeat alleles, express similar phenotypes as compared with heterozygous individuals [84]. Mutant allele repeat sizes range from $>50$ to 4000 (Table 1). Alleles with repeat sizes of 38 to 50 are termed premutations and do not result in DM1 phenotypes but are liable to repeat size expansion. As noted previously, more severe and earlier onset phenotypes have larger repeat expansions; the congenital form of the disease is associated with expansions of $>1000$ repeats, and mild phenotypes are associated with expansions of 51 to 149 repeats.

The presence of somatic mosaicism occurs because of instability of repeat size during mitotic divisions. In general, peripheral blood leukocyte expansion sizes are smaller as compared with expansion sizes in other tissues [85]. Somatic mosaicism of repeat sizes may partly explain the variability of phenotypic expression between different tissues as well as between individuals and among family members affected. Instability of premutation and mutant alleles (38 CTG repeats or greater) during meiosis underlies genetic anticipation. Congenital DM1, associated with large, $>1000$ to 2000 repeat expansions, is usually transmitted maternally and only rarely paternally [86-88]. Contraction of CTG repeat expansions can also occur, albeit less commonly (in about $5 \%$ of cases), and this is more common with paternal transmission [89].

The majority of evidence supports that a major pathogenic consequence of expanded CUG repeats in DM1 is an RNA toxic gain-of-function. The export of the expanded CUG RNAs is abnormal, and expanded CUG repeats form hairpin structures that bind and sequester RNA-binding proteins [90-92].

As RNA-binding proteins are sequestered (and therefore functionally depleted), this disrupts the splicing of RNA targets of these RNA-binding proteins. As a consequence, these RNA targets are alternatively spliced, resulting in altered protein isoforms. The most notable RNA-binding proteins affected by toxic ribonuclear foci include those in the muscleblindlike (MBNL) family and CUG RNA-binding protein (CUGBP) family with ETR-3-like factor (also known as CELF), that play important roles in RNA splicing, 
polyadenylation, stabilization, and translation [93, 94]. Specifically, the abnormal sequestration of MBNL and the abnormal stabilization of CELF ultimately lead to alternative splicing of many different premessenger RNAs in various tissues causing multisystemic effects. For example, splicing dysregulation of dystrobrevin 1, dystrophin, CLCN1, BIN1, and RYR1 all likely play roles in the development of muscle weakness and myotonia, whereas aberrant splicing of troponin $\mathrm{T}$ and Tau may lead to the cardiac and CNS manifestations, respectively [33, 95-100]. Splicing dysregulation becomes worse over time because CTG repeats are unstable and become larger during aging [101].

More recently discovered repeat-associated non-AUG (RAN) translation has gained attention and research is expanding in this area. RAN translation was first reported in DM1 and spinocerebellar ataxia type 8 in 2011 [102]. RAN translation has also been implicated in Fragile $\mathrm{X}$ tremor ataxia syndrome and C9ORF72 amyotrophic lateral sclerosis/ frontotemporal dementia [103]. It has become apparent that the DM1 disease mechanism could be related to a combination of RNA toxic gain-of-function and toxicity of RAN proteins $[102,104]$. RAN translation does not follow the traditional rules of RNA translation, as expansion can occur without an AUG start codon present and proceeds bidirectionally. Therefore, this translation mechanism contributes to toxic gain-of-function proteins, notably with patients expressing genetic anticipation, early-onset, and worsened prognosis [102].

Haploinsufficiency of $D M P K$ is not thought to be a major factor in pathogenesis. DMPK knock-out mice do not reproduce the multisystem phenotype but, interestingly, they do develop a late-onset myopathy [105]. Another hypothesis is that the CTG repeat expansion may alter neighboring genes [106]. Again, although alteration of neighboring genes has shown some features of the disease phenotype in knock-out mice, it does not fully explain the broad features seen in myotonic dystrophy patients.

\section{DM2}

DM2 is caused by an expanded and unstable tetranucleotide repeat (CCTG) in intron 1 of the CNBP gene (previously referred to has ZNF9) located on chromosome 3 [3]). Normal repeat length is 7 to 24 , and mutant alleles have repeat lengths of 75 to 11,000 repeats. Similar to DM1, intermediate repeat sizes are considered premutation and are more likely to expand during meiosis, increasing the risk of transmitting a mutant allele to offspring. In addition, there is some debate about whether a distinct threshold of repeat expansion number can be used to define repeat instability. There have been cases reported of repeat values less than 75 causing disease, suggesting that those with CCTG repeats between 25 and 75 may show incomplete penetrance [107]. Although the CCTG repeat expansion appears to be even more unstable as compared with the CTG repeat in DM1, repeat size in DM2 does not show correlations with disease severity or age of onset $[13$, 108].

The pathogenesis of DM2 has also been attributed to a toxic RNA gain-of-function with a reduction in available MBNL due to its abnormal sequestration into ribonuclear inclusions. Recent work showed competition between rbFOX1 and MBNL1 for binding to CCUG RNA repeats (but not CUG repeats in DM1), and this could explain differences in phenotype between DM1 and DM2 [109]. The role that CUGBP may play in DM2 is less clear as it has not been shown to be overexpressed in muscle biopsies from DM2 patients but is overexpressed in DM1 muscle biopsies [110]. In addition, haploinsufficiency may be a more important mechanism in DM2 than in DM1, although this is not universally agreed upon [111-113].

Recent work has shown that expansion mutations in DM2 are also bidirectionally expressed via RAN translation to produce tetrapeptide repeats (LPAC, leucine-proline-alaninecysteine and QAGR, glutamine-alanine-glycine-arginine, proteins, respectively) [114]. LPAC proteins were found in the gray matter of patient autopsy brain samples, whereas the QAGR proteins were found in the white matter regions of brains [114]. It has recently been suggested that during early disease progression, RNA toxic gain-of-function plays a more prominent role in disease progression, and that RAN translation mechanisms result in later progression of the disease [114].

\section{Emerging Therapeutic Strategies and Biomarkers}

Improved understanding of the molecular pathogenesis of the myotonic dystrophies has identified a number of potential therapeutic strategies. Reversal of the spliceopathy has been a major focus of new therapy development. A number of strategies have been investigated, including small molecule therapeutics, antisense oligonucleotide (ASO)-based therapy, and genome editing targeting either the expanded DNA, RNA, or downstream signaling pathways that are altered (Table 2). In addition to the development of potential therapies, much work is being done to develop and refine sensitive biomarkers with the hope that biomarkers will provide the ability to directly track disease severity, predict therapeutic response, and demonstrate target engagement in early phase trials [125]. One of the most promising strategies is measurement of alternatively spliced RNA products of predefined targets $[120,126]$. One challenge of such measures includes the invasiveness of muscle biopsy, although a disposable core needle for obtaining biopsies (albeit smaller size) has been used to reduce invasiveness. Nevertheless, many tissues that are important for symptom burden are inaccessible to biopsy, 
Table 2 Therapeutic strategies

\begin{tabular}{|c|c|c|c|c|}
\hline & Potential target & Strategies & Challenges & Examples \\
\hline \multirow[t]{2}{*}{ DNA } & $\begin{array}{l}\mathrm{CTG} / \mathrm{CCTG} \\
\text { repeat burden }\end{array}$ & Genome editing & Off target effects, distribution, immunogenicity? & van Agtmaal et al. [115] \\
\hline & $\begin{array}{l}\text { Increasing } \\
\text { CTG/CCTG } \\
\text { repeat size }\end{array}$ & $\begin{array}{l}\text { CAG-repeat ASOs to stabilize } \\
\text { repeat length }\end{array}$ & $\begin{array}{l}\text { Difficulties with suboptimal distribution of ASO } \\
\text { technology }\end{array}$ & Nakamori et al. [116] \\
\hline \multirow[t]{6}{*}{ RNA } & $\begin{array}{l}\text { Transcription of } \\
\text { CTG repeats }\end{array}$ & $\begin{array}{l}\text { Small molecule compounds to } \\
\text { inhibit transcription }\end{array}$ & $\begin{array}{l}\text { Nonspecific changes in transcription (off-target } \\
\text { effects) }\end{array}$ & $\begin{array}{l}\text { Siboni et al. [117], } \\
\text { Witherspoon et al. [118], } \\
\text { Coonrod et al. [119] }\end{array}$ \\
\hline & $\begin{array}{l}\text { Abnormal CUG } \\
\text { expansion }\end{array}$ & $\begin{array}{l}\text { Small molecule compounds to } \\
\text { block CUG repeat/MBNL1 in- } \\
\text { teractions }\end{array}$ & $\begin{array}{l}\text { Increased availability of repeat expansions? Increased } \\
\text { toxic foci due to reduced turnover of CUG } \\
\text { transcripts }\end{array}$ & $\begin{array}{l}\text { Nakamori et al. [120], Hoskins } \\
\text { et al. [121], Chen et al. [122] }\end{array}$ \\
\hline & \multirow[t]{4}{*}{$\begin{array}{l}\text { Alteration of } \\
\text { RBPs }\end{array}$} & $\begin{array}{l}\text { MBNL overexpression by using } \\
\text { AAV-mediated transduction }\end{array}$ & & Kanadia et al. [123] \\
\hline & & $\begin{array}{l}\text { MBNL overexpression by using } \\
\text { small molecule compounds }\end{array}$ & & Chen et al. [122] \\
\hline & & rbFOX1 overexpression (DM2) & & Sellier et al. [109] \\
\hline & & $\begin{array}{l}\text { Increased levels and stabilization of } \\
\text { CELF1 }\end{array}$ & & Wei [124] \\
\hline
\end{tabular}

Note: Some examples may work in multiple domains

i.e., the CNS. Therefore, much work needs to be done to better measure, understand, and track the multisystem effects of myotonic dystrophy.

\section{Small Molecule Therapeutics}

High-throughput screening of chemical libraries has been used in the field of myotonic dystrophy with the hope of discovery of small molecules with high affinity and specificity to the intended target. The theoretical benefits of small molecule compounds as compared to other strategies include cost of manufacturing, ease of oral delivery, and perhaps most importantly sufficient biodistribution, a feature that is necessary to address the multisystem effects of the disease. Thus far, many such compounds have been identified that target different aspects of the disease mechanism. One of the more common therapeutic strategies has been the development of compounds that bind to expanded CUG transcripts, which can have a number of effects, including a decrease in the formation of toxic ribonuclear foci or freeing sequestered MBNL [127, 128]. Historically, small molecules targeting RNA have been difficult to develop for many reasons, including limited tertiary structure and the anionic nature of RNA repeats (therefore impeding specificity and increasing liability for off-target effects). Nevertheless, 1 molecule that binds to CUG repeats, developed by Rzuczek and colleagues, has been shown to improve MBNL1-dependent pre-mRNA splicing defects in DM1-affected cells and was more potent when compared to a morpholino ASO [127]. The increased potency of the small molecule was thought to be because of the recognition of RNA structure rather than the RNA sequence. Erythromycin has been shown to work by a similar mechanism, and oral administration in a DM1 mouse model led to a reduction in ribonuclear foci formation and splicing abnormalities [120]. As another example, pentamidine, an antibiotic traditionally used to treat pneumocystis pneumonia, was also identified as a compound able to disrupt MBNL1 binding in vitro [129]. However, later studies have demonstrated that pentamidine may actually work upstream by inhibiting transcription of the mutant CTG repeats which is similar to the mechanism of actinomycin D shown in cell and mouse models $[117,119]$. There are also molecules in development that are able to work through multiple mechanisms - binding to the CTG DNA repeats, binding to the CUG RNA repeats, and cleaving the CUG repeats, which has obvious possible advantages to only targeting 1 step in the pathogenesis [130].

Small molecules have also been designed to target pathways more downstream, such as inducing overexpression of MBNL1, a method that has shown promising results [122]. Another molecule currently in the spotlight is tideglusib, a selective and irreversible non-ATP-competitive glycogen synthase kinase 3 inhibitor. It is thought that glycogen synthase kinase 3 activity is increased in DM1, leading to stabilization and increased levels of CELF1, subsequently causing changes in CELF-regulated RNA splicing as mentioned above [124, 131]. A phase II clinical trial of tideglusib (NCT02858908) for patients' ages 12 to 45 years old with congenital and juvenile-onset DM1 was recently completed with results forthcoming. Other avenues being investigated include protein kinase $\mathrm{C}$ inhibition due to its role in hyperphosphorylation of CELF proteins, normalization of the AMP-activated protein kinase/mammalian target of rapamycin pathway and blocking the tumor necrosis factor-like weak inducer of apoptosis/ fibroblast growth factor-inducible 14 [132-135]. 


\section{Posttranscriptional Gene Silencing Using Nucleotide Sequences}

The use of ASOs is an important recent therapeutic strategy in the treatment of genetic neuromuscular disorders [136]. They consist of a strand of nucleotides that bind to specific hnRNAs or mRNAs and require modification so that they are not degraded in vivo and, therefore, reach the target tissue. In the case of myotonic dystrophy, ASOs can interfere with the binding between MBNL and the pathogenic RNA, similar to many of the small molecules previously mentioned, either by targeting the CUG-repeat expansion directly or by targeting a flanking sequence. Several ASOs have shown efficacy in vitro and in vivo in transgenic mice and nonhuman primates [137-140]. One ASO developed by Ionis Pharmaceuticals entered a phase I/IIa multiple ascending dose study (IONISDMPKRX). Unfortunately, the ASO did not reach the sufficient concentration in muscle due to inadequate biodistribution, and thus, the trial was stopped early. Small interfering RNA and short hairpin RNA have also shown some efficacy in preclinical studies but have yet to reach clinical trial readiness [101, 141, 142].

\section{Genome Editing}

The wide-reaching effects of genome editing, particularly with CRISPR/Cas9, have yet to be seen. So far, it is clear that this revolutionary technology has the potential to treat monogenic disorders, including myotonic dystrophy, but a number of challenges have to be first surmounted. To put it simply, a Cas9 nuclease is complexed with a guide RNA that targets a specific genomic locus. The nuclease cuts the DNA at the target location, thus correcting the genetic defect. The benefit (and potential drawback) to this approach is that genetic defects are permanently changed, whereas other methods, such as ASOs, require repeated administration. The chief concerns surrounding this approach are similar to the other proposed strategies: possible nonspecific/off-target effects and immunogenicity to either the genome editing components or delivery particles, particularly if a viral vector-mediated delivery system is used. In addition, perhaps 1 of the biggest challenges is distribution and ensuring the target tissue is reached, a problem highlighted by the first ASO clinical trial discussed above [143]. Nevertheless, in vitro genome editing studies in DM1 have been promising. One study using myoblasts from transgenic mice found that dual cleavage at both sides of the CTG expansion led to complete and precise excision of the repeat. Removal of the repeat did not have any detrimental effects on the expression of neighboring genes and was able to eliminate RNA ribonuclear foci and eliminate abnormal splicing [115]. Another study demonstrated similar efficacy using a different protocol in cell models from different DM1 patients [144]. Yet another study was able to use the CRISPR/Cas9 system to eliminate the repeat expansions in human cells using a smaller version that was optimized for possible adeno-associated virus packaging [145].

Although many studies concentrate on genome modification of terminally differentiated somatic cells, some have examined the use of genome editing of induced pluripotent stem cells that could be used for developing autologous stem cell therapy $[146,147]$. Placement of polyA signals upstream of the CTG expansion using transcription activator-like effector nucleases, a different genome editing tool than CRISPR/Cas9, was able to stop the production of the mutant transcripts. These cells maintained pluripotency and were able to differentiate into normal neurons and cardiomyocytes in vivo [146].

\section{Conclusions}

The myotonic dystrophies are complex multisystem disorders that are currently managed with supportive care to address a multitude of skeletal muscle, cardiac, endocrine, and CNS symptoms, among other effects of the disease. There is still much work to be done to improve understanding of symptom burden and effects of the disease on patients' lives as well as how to reduce this burden. Exciting developments have identified potential therapeutic targets that, if engaged, should result in improved disease phenotype. The biggest challenges appear to be the design of therapeutics that can reach the target tissues, such as visceral organs, cardiac muscle, skeletal muscle, and CNS. This is not a minor task considering the currently available strategies and limitations. The discovery and refinement of sensitive stratifying, pharmacodynamic, and therapeutic efficacy biomarkers will allow tractable disease response (or nonresponse) and therefore rapid clinical trial implementation. There is, in particular, an ongoing need for biomarkers that can demonstrate target engagement and early therapeutic response in inaccessible tissues, such as the CNS, as disease effects in these tissues represent a major source of disease and symptom burden.

Acknowledgments W. David Arnold has received support from an investigator-initiated clinical trial grant from Gilead Sciences and Benjamin Weiner was supported by the Ohio State University College of Medicine (Roessler Research Scholarship).

Required Author Forms Disclosure forms provided by the authors are available with the online version of this article.

\section{References}

1. Emery AEH. Population frequencies of inherited neuromuscular diseases - a world survey. Neuromuscul Disord 1991;1:19-29.

2. Suominen T, Bachinski LL, Auvinen S, Hackman P, Baggerly $\mathrm{KA}$, Angelini $\mathrm{C}$ et al. Population frequency of myotonic dystrophy: higher than expected frequency of myotonic dystrophy type 2 
(DM2) mutation in Finland. Eur J Hum Genet. 2011;19:776-782. https://doi.org/10.1038/ejhg.2011.23.

3. Liquori CL, Ricker K, Moseley ML, Jacobsen JF, Kress W, Naylor SL et al. Myotonic dystrophy type 2 caused by a CCTG expansion in intron 1 of ZNF9. Science 2001;293:864-867. https://doi.org/10.1126/science.1062125.

4. Hilbert JE, Ashizawa T, Day JW, Luebbe EA, Martens WB, McDermott MP et al. Diagnostic odyssey of patients with myotonic dystrophy. J Neurol 2013;260:2497-2504. https://doi.org/ 10.1007/s00415-013-6993-0.

5. De Antonio M, Dogan C, Hamroun D, Mati M, Zerrouki S, Eymard B et al. Unravelling the myotonic dystrophy type 1 clinical spectrum: a systematic registry-based study with implications for disease classification. Rev Neurol 2016;172:572-580. https:// doi.org/10.1016/j.neurol.2016.08.003.

6. Ho G, Cardamone M, Farrar M. Congenital and childhood myotonic dystrophy: current aspects of disease and future directions. World J Clin Pediatr 2015;4:66-80. https://doi.org/10.5409/wjcp. v4.i4.66.

7. Theadom A, Rodrigues M, Roxburgh R. Knowledge of sub-types important to understanding of the prevalence of myotonic dystrophy. Neuroepidemiology 2016;46:228. https://doi.org/10.1159/ 000444469

8. Thornton CA. Myotonic dystrophy. Neurol Clin 2014;32:705719, viii. https://doi.org/10.1016/j.ncl.2014.04.011.

9. Mejersjo C, Kiliaridis S. Temporomandibular dysfunction in adult patients with myotonic dystrophy (DM1). J Oral Rehabil 2017;44: 749-755. https://doi.org/10.1111/joor.12534.

10. Campbell C, Levin S, Siu VM, Venance S, Jacob P. Congenital myotonic dystrophy: Canadian population-based surveillance study. J Pediatr 2013;163:120-5.e1-120-5.e3. https://doi.org/10. 1016/j.jpeds.2012.12.070

11. Echenne B, Bassez G. Congenital and infantile myotonic dystrophy. Handb Clin Neurol 2013;113:1387-1393. https://doi.org/10. 1016/b978-0-444-59565-2.00009-5.

12. Dogan $\mathrm{C}$, De Antonio M, Hamroun D, Varet H, Fabbro M, Rougier $\mathrm{F}$ et al. Gender as a modifying factor influencing myotonic dystrophy type 1 phenotype severity and mortality: a nationwide multiple databases cross-sectional observational study. PLoS ONE 2016;11:e0148264. https://doi.org/10.1371/journal.pone. 0148264 .

13. Day JW, Ricker K, Jacobsen JF, Rasmussen LJ, Dick KA, Kress W et al. Myotonic dystrophy type 2: molecular, diagnostic and clinical spectrum. Neurology 2003;60:657-664.

14. Montagnese F, Mondello S, Wenninger S, Kress W, Schoser B. Assessing the influence of age and gender on the phenotype of myotonic dystrophy type 2. J Neurol 2017;264:2472-2480. https://doi.org/10.1007/s00415-017-8653-2.

15. Peric M, Peric S, Rapajic N, Dobricic V, Savic-Pavicevic D, Nesic I et al. Multidimensional aspects of pain in myotonic dystrophies. Acta Myol 2015;34:126-132.

16. Miro J, Gertz KJ, Carter GT, Jensen MP. Pain location and intensity impacts function in persons with myotonic dystrophy type 1 and facioscapulohumeral dystrophy with chronic pain. Muscle Nerve 2014;49:900-905. https://doi.org/10.1002/mus.24079.

17. Kierkegaard M, Harms-Ringdahl K, Edstrom L, Widen Holmqvist L, Tollback A. Feasibility and effects of a physical exercise programme in adults with myotonic dystrophy type 1: a randomized controlled pilot study. J Rehabil Med 2011;43:695-702. https:/ doi.org/10.2340/16501977-0833.

18. Brady LI, MacNeil LG, Tarnopolsky MA. Impact of habitual exercise on the strength of individuals with myotonic dystrophy type 1. Am J Phys Med Rehabil 2014;93:739-746; quiz 47-8. https:// doi.org/10.1097/phm.0000000000000088.

19. Lindeman E, Leffers P, Spaans F, Drukker J, Reulen J, Kerckhoffs $\mathrm{M}$ et al. Strength training in patients with myotonic dystrophy and hereditary motor and sensory neuropathy: a randomized clinical trial. Arch Phys Med Rehabil 1995;76:612-620.

20. Orngreen MC, Olsen DB, Vissing J. Aerobic training in patients with myotonic dystrophy type 1. Ann Neurol 2005;57:754-757. https://doi.org/10.1002/ana.20460.

21. Mnatsakanian A, Kissel JT, Terry P, King WM. One clinic's experience with carbon fiber orthoses in neuromuscular disease. Muscle Nerve 2017;55:202-205. https://doi.org/10.1002/mus. 25233.

22. Logigian EL, Moxley RT, Blood CL, Barbieri CA, Martens WB, Wiegner AW et al. Leukocyte CTG repeat length correlates with severity of myotonia in myotonic dystrophy type 1. Neurology 2004;62:1081-1089. https://doi.org/10.1212/01.wnl. 0000118206.49652.a3.

23. Meola G, Cardani R. Myotonic dystrophy type 2 and modifier genes: an update on clinical and pathomolecular aspects. Neurol Sci 2017;38:535-546. https://doi.org/10.1007/s10072-016-28055 .

24. Bugiardini E, Rivolta I, Binda A, et al. SCN4A mutation as modifying factor of myotonic dystrophy type 2 phenotype. Neuromuscul Disord. 2015;25:301-307. https://doi.org/10.1016/ j.nmd.2015.01.006.

25. Cardani R. Sci Rep https://doi.org/10.1038/s41598-018-29302-z.

26. Binda A, Renna LV, Bose F, Brigonzi E, Botta A, Valaperta R et al. SCN4A as modifier gene in patients with myotonic dystrophy type 2. Sci Rep. 2018;8:11058. https://doi.org/10.1038/s41598018-29302-z

27. Logigian EL, Martens WB, Moxley RTt, McDermott MP, Dilek $\mathrm{N}$, Wiegner AW et al. Mexiletine is an effective antimyotonia treatment in myotonic dystrophy type 1. Neurology 2010;74: 1441-1448. https://doi.org/10.1212/WNL.0b013e3181dc1a3a.

28. Novak KR, Norman J, Mitchell JR, Pinter MJ, Rich MM. Sodium channel slow inactivation as a therapeutic target for myotonia congenita. Ann Neurol 2015;77:320-332. https://doi.org/10. 1002/ana.24331.

29. Arnold WD, Kline D, Sanderson A, Hawash AA, Bartlett A, Novak KR et al. Open-label trial of ranolazine for the treatment of myotonia congenita. Neurology 2017. https://doi.org/10.1212/ wnl.0000000000004229.

30. LoRusso S, Kline D, Bartlett A, Agriesti J, Freimer M, Rich M et al. Open label trial of ranolazine for the treatment of paramyotonia congenita (P3.436). Neurology. 2018;90(15 Supplement).

31. Andersen G, Hedermann G, Witting N, Duno M, Andersen H, Vissing J. The antimyotonic effect of lamotrigine in nondystrophic myotonias: a double-blind randomized study. Brain 2017;140:2295-2305. https://doi.org/10.1093/brain/awx192.

32. Lawless M, Arnold W, Agriesti J, Moravec T, Moravec T, Moravec T. Investigation of ranolazine as an anti-myotonia treatment in myotonic dystrophy type 1 (P5.443). Neurology. 2018;90(15 Supplement).

33. Gourdon G, Meola G. Myotonic dystrophies: state of the art of new therapeutic developments for the CNS. Front Cell Neurosci 2017;11:101. https://doi.org/10.3389/fncel.2017.00101.

34. Zalonis I, Bonakis A, Christidi F, Vagiakis E, Papageorgiou SG, Kalfakis $\mathrm{N}$ et al. Toward understanding cognitive impairment in patients with myotonic dystrophy type 1. Arch Clin Neuropsychol. 2010;25:303-313. https://doi.org/10.1093/arclin/ acq016.

35. Baldanzi S, Ricci G, Bottari M, Chico L, Simoncini C, Siciliano G. The proposal of a clinical protocol to assess central and peripheral fatigue in myotonic dystrophy type 1. Arch Ital Biol. 2017;155:43-53. https://doi.org/10.12871/000398292017125.

36. Belanger AY, McComas AJ. Contractile properties of muscles in myotonic dystrophy. J Neurol Neurosurg Psychiatry 1983;46: 625-631. 
37. Annane D, Moore DH, Barnes PR, Miller RG. Psychostimulants for hypersomnia (excessive daytime sleepiness) in myotonic dystrophy. Cochrane Database Syst Rev 2006(3):Cd003218. https:// doi.org/10.1002/14651858.CD003218.pub2.

38. Wintzen AR, Lammers GJ, van Dijk JG. Does modafinil enhance activity of patients with myotonic dystrophy?: a double-blind placebo-controlled crossover study. J Neurol 2007;254:26-28. https://doi.org/10.1007/s00415-006-0186-z.

39. Hilton-Jones D, Bowler M, Lochmueller H, Longman C, Petty R, Roberts $\mathrm{M}$ et al. Modafinil for excessive daytime sleepiness in myotonic dystrophy type 1 -the patients' perspective. Neuromuscul Disord. 2012;22:597-603. https://doi.org/10.1016/ j.nmd.2012.02.005.

40. Rakocevic-Stojanovic V, Peric S, Madzarevic R, Dobricic V, Ralic $\mathrm{V}$, Ilic V et al. Significant impact of behavioral and cognitive impairment on quality of life in patients with myotonic dystrophy type 1. Clin Neurol Neurosurg 2014;126:76-81. https://doi.org/ 10.1016/j.clineuro.2014.08.021.

41. Peric S, Rakocevic Stojanovic V, Mandic Stojmenovic G, Ilic V, Kovacevic M, Parojcic A et al. Clusters of cognitive impairment among different phenotypes of myotonic dystrophy type 1 and type 2. Neurol Sci. 2017;38:415-423. https://doi.org/10.1007/ s10072-016-2778-4.

42. Jean S, Richer L, Laberge L, Mathieu J. Comparisons of intellectual capacities between mild and classic adult-onset phenotypes of myotonic dystrophy type 1 (DM1). Orphanet J Rare Dis 2014;9: 186. https://doi.org/10.1186/s13023-014-0186-5.

43. Sergeant N, Sablonniere B, Schraen-Maschke S, Ghestem A, Maurage CA, Wattez A et al. Dysregulation of human brain microtubule-associated tau mRNA maturation in myotonic dystrophy type 1. Hum Mol Genet 2001;10:2143-2155.

44. Nojszewska M, Lusakowska A, Szmidt-Salkowska E, Gawel M, Lipowska M, Sulek A et al. Peripheral nerve involvement in myotonic dystrophy type 2-similar or different than in myotonic dystrophy type 1? Neurol Neurochir Pol 2015;49:164-170. https:// doi.org/10.1016/j.pjnns.2015.04.008.

45. Hermans MC, Faber CG, Vanhoutte EK, Bakkers M, De Baets $\mathrm{MH}$, de Die-Smulders CE et al. Peripheral neuropathy in myotonic dystrophy type 1. J Peripherl Nerv Syst. 2011;16:24-29. https:// doi.org/10.1111/j.1529-8027.2011.00313.x.

46. Angelini C, Di Leo R, Cudia P. Autonomic regulation in muscular dystrophy. Front Physiol 2013;4:257. https://doi.org/10.3389/ fphys.2013.00257.

47. Mathieu J, Allard P, Potvin L, Prevost C, Begin P. A 10-year study of mortality in a cohort of patients with myotonic dystrophy. Neurology 1999;52:1658-1662.

48. Poussel M, Kaminsky P, Renaud P, Laroppe J, Pruna L, Chenuel $B$. Supine changes in lung function correlate with chronic respiratory failure in myotonic dystrophy patients. Respir Physiol Neurobiol 2014;193:43-51. https://doi.org/10.1016/j.resp.2014. 01.006 .

49. Sansone VA, Gagnon C. 207th ENMC Workshop on chronic respiratory insufficiency in myotonic dystrophies: management and implications for research, 27-29 June 2014, Naarden, The Netherlands. Neuromuscul Disord. 2015;25:432-442. https://doi.org/10.1016/j.nmd.2015.01.011.

50. Poussel M, Thil C, Kaminsky P, Mercy M, Gomez E, Chaouat A et al. Lack of correlation between the ventilatory response to $\mathrm{CO} 2$ and lung function impairment in myotonic dystrophy patients: evidence for a dysregulation at central level. Neuromuscul Disord. 2015;25:403-408. https://doi.org/10.1016/j.nmd.2015. 02.006 .

51. Leonardis L, Blagus R, Dolenc Groselj L. Sleep and breathing disorders in myotonic dystrophy type 2. Acta Neurol Scand 2015;132:42-48. https://doi.org/10.1111/ane.12355.
52. Pincherle A, Patruno V, Raimondi P, Moretti S, Dominese A, Martinelli-Boneschi $\mathrm{F}$ et al. Sleep breathing disorders in 40 Italian patients with Myotonic dystrophy type 1 . Neuromuscul Disord. 2012;22:219-224. https://doi.org/10.1016/j.nmd.2011. 08.010 .

53. Boussaid G, Prigent H, Laforet P, Raphael JC, Annane D, Orlikowski D et al. Effect and impact of mechanical ventilation in myotonic dystrophy type 1: a prospective cohort study. Thorax 2018. https://doi.org/10.1136/thoraxjnl-2017-210610.

54. Church SC. The heart in myotonia atrophica. Arch Intern Med 1967;119:176-181.

55. Bhakta D, Lowe MR, Groh WJ. Prevalence of structural cardiac abnormalities in patients with myotonic dystrophy type I. Am Heart J 2004;147:224-227. https://doi.org/10.1016/j.ahj.2003.08. 008.

56. Melacini P, Villanova C, Menegazzo E, Novelli G, Danieli G, Rizzoli $\mathrm{G}$ et al. Correlation between cardiac involvement and CTG trinucleotide repeat length in myotonic dystrophy. J Am Coll Cardiol 1995;25:239-245.

57. Clarke NRA, Kelion AD, Nixon J, Hilton-Jones D, Forfar JC. Does cytosine-thymine-guanine (CTG) expansion size predict cardiac events and electrocardiographic progression in myotonic dystrophy?, Heart 2001;86:411-416.

58. Hardin BA, Lowe MR, Bhakta D, Groh WJ. Heart rate variability declines with increasing age and CTG repeat length in patients with myotonic dystrophy type 1 . Ann Noninvasive Electrocardiol 2003;8:227-232. https://doi.org/10.1046/j.1542474X.2003.08310.x.

59. Prystowsky EN, Pritchett EL, Roses AD, Gallagher J. The natural history of conduction system disease in myotonic muscular dystrophy as determined by serial electrophysiologic studies. Circulation 1979;60:1360-1364.

60. Pelargonio G, Dello Russo A, Sanna T, De Martino G, Bellocci F. Myotonic dystrophy and the heart. Heart 2002;88:665-670.

61. Grigg LE, Chan W, Mond HG, Vohra JK, Downey WF. Ventricular tachycardia and sudden death in myotonic dystrophy: clinical, electrophysiologic and pathologic features. J Am Coll Cardiol 1985;6:254-256. https://doi.org/10.1016/S07351097(85)80286-2.

62. Merino JL, Carmona JR, Fernández-Lozano I, Peinado R, Basterra N, Sobrino JA. Mechanisms of sustained ventricular tachycardia in myotonic dystrophy: implications for catheter ablation. Circulation 1998;98:541-546. https://doi.org/10.1161/01. CIR.98.6.541.

63. Lau JK, Sy RW, Corbett A, Kritharides L. Myotonic dystrophy and the heart: a systematic review of evaluation and management. Int J Cardiol 2015;184:600-608. https://doi.org/10.1016/j.ijcard. 2015.03.069.

64. Ludatscher RM, Kerner H, Amikam S, Gellei B. Myotonia dystrophica with heart involvement: an electron microscopic study of skeletal, cardiac, and smooth muscle. J Clin Pathol 1978;31:1057-1064.

65. Motta J, Guilleminault C, Billingham M, Barry W, Mason J. Cardiac abnormalities in myotonic dystrophy. Electrophysiologic and histopathologic studies. Am J Med 1979;67:467-673.

66. Nguyen HH, Wolfe JT, 3rd, Holmes DR, Jr., Edwards WD. Pathology of the cardiac conduction system in myotonic dystrophy: a study of 12 cases. J Am Coll Cardiol 1988;11:662-671.

67. Sansone VA, Brigonzi E, Schoser B, Villani S, Gaeta M, De Ambroggi $\mathrm{G}$ et al. The frequency and severity of cardiac involvement in myotonic dystrophy type 2 (DM2): long-term outcomes. Int J Cardiol 2013;168:1147-1153. https://doi.org/10.1016/j. ijcard.2012.11.076.

68. Duboc D, Wahbi K. What is the best way to detect infra-Hisian conduction abnormalities and prevent sudden cardiac death in 
myotonic dystrophy?, Heart 2012;98:433-434. https://doi.org/10. 1136/heartjnl-2011-301407.

69. Verhaert D, Richards K, Rafael-Fortney JA, Raman SV. Cardiac involvement in patients with muscular dystrophies: magnetic resonance imaging phenotype and genotypic considerations. Circ Cardiovasc Imaging 2011;4:67-76. https://doi.org/10.1161/ circimaging.110.960740.

70. Wahbi K, Meune C, Porcher R, Bećane HM, Lazarus A, Laforêt P et al. Electrophysiological study with prophylactic pacing and survival in adults with myotonic dystrophy and conduction system disease. JAMA. 2012;307:1292-1301. https://doi.org/10.1001/ jama.2012.346.

71. Hilbert JE, Barohn RJ, Clemens PR, Luebbe EA, Martens WB, McDermott MP et al. High frequency of gastrointestinal manifestations in myotonic dystrophy type 1 and type 2. Neurology 2017;89:1348-1354. https://doi.org/10.1212/wnl. 0000000000004420

72. Brunner HG, Hamel BC, Rieu P, Howeler CJ, Peters FT. Intestinal pseudo-obstruction in myotonic dystrophy. J Med Genet 1992;29: 791-793.

73. Abercrombie JF, Rogers J, Swash M. Faecal incontinence in myotonic dystrophy. J Neurol Neurosurg Psychiatry 1998;64:128130 .

74. Degraeuwe J, Van Laecke E, De Muynck M, Van Biervliet S, Vande Velde S, Van Winckel M. Faecal incontinence due to atrophy of the anal sphincter in myotonic dystrophy: a case report. Acta Gastroenterol Belg 2011;74:88-90.

75. Bellini M, Biagi S, Stasi C, Costa F, Mumolo MG, Ricchiuti A et al. Gastrointestinal manifestations in myotonic muscular dystrophy. World J Gastroenterol. 2006;12:1821-1828. https://doi. org/10.3748/wjg.v12.i12.1821.

76. Marcon M, Briani C, Ermani M, Menegazzo E, Iurilli V, Feltrin GP et al. Positive correlation of CTG expansion and pharyngoesophageal alterations in myotonic dystrophy patients. Ital J Neurol Sci 1998;19:75-80.

77. Tarnopolsky MA, Pearce E, Matteliano A, James C, Armstrong D. Bacterial overgrowth syndrome in myotonic muscular dystrophy is potentially treatable. Muscle Nerve 2010;42:853-855. https:// doi.org/10.1002/mus.21787.

78. Voermans NC, Erasmus CE, Ockeloen CW, Van Engelen BG, Eggink CA. Primary cataract as a key to recognition of myotonic dystrophy type 1. Eur J Ophthalmol 2015;25:e46-e49. https://doi. org/10.5301/ejo.5000565.

79. Wochner RD, Drews G, Strober W, Waldmann TA. Accelerated breakdown of immunoglobulin $\mathrm{G}(\mathrm{IgG})$ in myotonic dystrophy: a hereditary error of immunoglobulin catabolism. J Clin Investig 1966;45:321-329.

80. Kaminsky P, Lesesve JF, Jonveaux P, Pruna L. IgG deficiency and expansion of CTG repeats in myotonic dystrophy. Clin Neurol Neurosurg 2011;113:464-468. https://doi.org/10.1016/j.clineuro. 2011.02.003

81. Gadalla SM, Lund M, Pfeiffer RM, Gortz S, Mueller CM, Moxley RT, 3rd et al. Cancer risk among patients with myotonic muscular dystrophy. JAMA 2011;306:2480-2486. https://doi.org/10.1001/ jama.2011.1796.

82. Dahlqvist JR, Orngreen MC, Witting N, Vissing J. Endocrine function over time in patients with myotonic dystrophy type 1 . Eur J Neurol 2015;22:116-122. https://doi.org/10.1111/ene. 12542.

83. Brook JD, McCurrach ME, Harley HG, Buckler AJ, Church D, Aburatani $\mathrm{H}$ et al. Molecular basis of myotonic dystrophy: expansion of a trinucleotide (CTG) repeat at the $3^{\prime}$ end of a transcript encoding a protein kinase family member. Cell 1992;68:799-808. https://doi.org/10.1016/0092-8674(92)90154-5.
84. Martorell L, Illa I, Rosell J, Benitez J, Sedano MJ, Baiget M. Homozygous myotonic dystrophy: clinical and molecular studies of three unrelated cases. J Med Genet 1996;33:783-785.

85. Thornton CA, Johnson K, Moxley RT, III. Myotonic dystrophy patients have larger CTG expansions in skeletal muscle than in leukocytes. Ann Neurol 1994;35:104-107. https://doi.org/10. 1002/ana.410350116.

86. Bergoffen J, Kant J, Sladky J, McDonald-McGinn D, Zackai EH, Fischbeck KH. Paternal transmission of congenital myotonic dystrophy. J Med Genet 1994;31:518-520.

87. Zeesman S, Carson N, Whelan DT. Paternal transmission of the congenital form of myotonic dystrophy type 1: a new case and review of the literature. Am J Med Genet 2002;107:222-226.

88. Barbé L, Lanni S, López-Castel A, Franck S, Spits C, Keymolen $\mathrm{K}$ et al. $\mathrm{CpG}$ methylation, a parent-of-origin effect for maternalbiased transmission of congenital myotonic dystrophy. Am J Hum Genet 2017;100:488-505. https://doi.org/10.1016/j.ajhg.2017.01. 033.

89. Ashizawa T, Anvret M, Baiget M, Barcelo JM, Brunner H, Cobo $\mathrm{AM}$ et al. Characteristics of intergenerational contractions of the CTG repeat in myotonic dystrophy. Am J Hum Genet 1994;54: 414-423.

90. Tian B, White RJ, Xia T, Welle S, Turner DH, Mathews MB et al Expanded CUG repeat RNAs form hairpins that activate the double-stranded RNA-dependent protein kinase PKR. RNA 2000;6:79-87.

91. Michalowski S, Miller JW, Urbinati CR, Paliouras M, Swanson MS, Griffith J. Visualization of double-stranded RNAs from the myotonic dystrophy protein kinase gene and interactions with CUG-binding protein. Nucleic Acids Res 1999;27:3534-3542.

92. Mooers BH, Logue JS, Berglund JA. The structural basis of myotonic dystrophy from the crystal structure of CUG repeats. Proc Natl Acad Sci U S A 2005;102:16626-16631. https://doi.org/10. 1073/pnas.0505873102.

93. Mateos-Aierdi AJ, Goicoechea M, Aiastui A, Fernandez-Torron R, Garcia-Puga M, Matheu A et al. Muscle wasting in myotonic dystrophies: a model of premature aging. Front Aging Neurosci 2015;7:125. https://doi.org/10.3389/fnagi.2015.00125.

94. Caillet-Boudin ML, Fernandez-Gomez FJ, Tran H, Dhaenens CM, Buee L, Sergeant N. Brain pathology in myotonic dystrophy: when tauopathy meets spliceopathy and RNAopathy. Front Mol Neurosci 2014;6:57. https://doi.org/10.3389/fnmol.2013.00057.

95. Sansone VA. The dystrophic and nondystrophic myotonias. Continuum (Minneapolis, Minn) 2016;22:1889-1915. https:// doi.org/10.1212/con.0000000000000414.

96. Fugier C, Klein AF, Hammer C, Vassilopoulos S, Ivarsson Y, Toussaint A et al. Misregulated alternative splicing of BIN1 is associated with $\mathrm{T}$ tubule alterations and muscle weakness in myotonic dystrophy. Nat Med 2011;17:720-725. https://doi.org/10. 1038/nm.2374.

97. Charlet-B N, Savkur RS, Singh G, Philips AV, Grice EA, Cooper TA. Loss of the muscle-specific chloride channel in type 1 myotonic dystrophy due to misregulated alternative splicing. Mol Cell 2002;10:45-53. https://doi.org/10.1016/S1097-2765(02)00572-5.

98. Philips AV, Timchenko LT, Cooper TA. Disruption of splicing regulated by a CUG-binding protein in myotonic dystrophy. Science 1998;280:737-741.

99. Nakamori M, Kimura T, Fujimura H, Takahashi MP, Sakoda S. Altered mRNA splicing of dystrophin in type 1 myotonic dystrophy. Muscle Nerve 2007;36:251-257. https://doi.org/10.1002/ mus.20809.

100. Nakamori M, Sobczak K, Puwanant A, Welle S, Eichinger K, Pandya $\mathrm{S}$ et al. Splicing biomarkers of disease severity in myotonic dystrophy. Ann Neurol 2013;74:862-872. https://doi.org/10. 1002/ana.23992. 
101. Thornton CA, Wang E, Carrell EM. Myotonic dystrophy: approach to therapy. Curr Opin Genet Dev 2017;44:135-140. https://doi.org/10.1016/j.gde.2017.03.007.

102. $\mathrm{Zu} \mathrm{T}$, Gibbens B, Doty NS, Gomes-Pereira M, Huguet A, Stone MD et al. Non-ATG-initiated translation directed by microsatellite expansions. Proc Natl Acad Sci U S A. 2011;108:260-265. https:// doi.org/10.1073/pnas.1013343108.

103. Cleary JD, Ranum LP. Repeat-associated non-ATG (RAN) translation in neurological disease. Hum Mol Genet 2013;22:R45R51. https://doi.org/10.1093/hmg/ddt371.

104. Klein AF, Gasnier E, Furling D. Gain of RNA function in pathological cases: focus on myotonic dystrophy. Biochimie 2011;93: 2006-2012. https://doi.org/10.1016/j.biochi.2011.06.028.

105. Berul CI, Maguire CT, Aronovitz MJ, Greenwood J, Miller C, Gehrmann J et al. DMPK dosage alterations result in atrioventricular conduction abnormalities in a mouse myotonic dystrophy model. J Clin Invest 1999;103:R1-R7. https://doi.org/10.1172/ jci5346.

106. Thornton CA, Wymer JP, Simmons Z, McClain C, Moxley RT, 3rd. Expansion of the myotonic dystrophy CTG repeat reduces expression of the flanking DMAHP gene. Nat Genet 1997;16: 407-409. https://doi.org/10.1038/ng0897-407.

107. Mahyera AS, Schneider T, Halliger-Keller B, Schrooten K, Horner EM, Rost $\mathrm{S}$ et al. Distribution and structure of DM2 repeat tract alleles in the German population. Front Neurol 2018;9:463. https://doi.org/10.3389/fneur.2018.00463.

108. Meola G, Cardani R. Myotonic dystrophy type 2: an update on clinical aspects, genetic and pathomolecular mechanism. J Neuromuscul Dis 2015;2:S59-S71. https://doi.org/10.3233/JND150088.

109. Sellier C, Cerro-Herreros E, Blatter M, Freyermuth F, Gaucherot A, Ruffenach $\mathrm{F}$ et al. rbFOX1/MBNL1 competition for CCUG RNA repeats binding contributes to myotonic dystrophy type 1/ type 2 differences. Nat Commun 2018;9:2009. https://doi.org/10. 1038/s41467-018-04370-x.

110. Cardani R, Bugiardini E, Renna LV, Rossi G, Colombo G, Valaperta R et al. Overexpression of CUGBP1 in skeletal muscle from adult classic myotonic dystrophy type 1 but not from myotonic dystrophy type 2. PLoS One 2013;8:e83777. https://doi.org/ 10.1371/journal.pone.0083777.

111. Chen W, Wang Y, Abe Y, Cheney L, Udd B, Li YP. Haploinsuffciency for Znf9 in Znf9+/- mice is associated with multiorgan abnormalities resembling myotonic dystrophy. J Mol Biol 2007;368:8-17. https://doi.org/10.1016/j.jmb.2007.01.088.

112. Raheem O, Olufemi SE, Bachinski LL, Vihola A, Sirito M, Holmlund-Hampf J et al. Mutant (CCTG)n expansion causes abnormal expression of zinc finger protein 9 (ZNF9) in myotonic dystrophy type 2. Am J Pathol 2010;177:3025-3036. https://doi. org/10.2353/ajpath.2010.100179.

113. Margolis JM, Schoser BG, Moseley ML, Day JW, Ranum LP. DM2 intronic expansions: evidence for CCUG accumulation without flanking sequence or effects on ZNF9 mRNA processing or protein expression. Hum Mol Genet 2006;15:1808-1815. https://doi.org/10.1093/hmg/ddl103.

114. Zu T, Cleary JD, Liu Y, Banez-Coronel M, Bubenik JL, Ayhan F et al. RAN translation regulated by muscleblind proteins in myotonic dystrophy type 2. Neuron 2017;95:1292.e5-1305.e5. https:// doi.org/10.1016/j.neuron.2017.08.039.

115. van Agtmaal EL, Andre LM, Willemse M, Cumming SA, van Kessel IDG, van den Broek W et al. CRISPR/Cas9-induced (CTGCAG)n repeat instability in the myotonic dystrophy type 1 locus: implications for therapeutic genome editing. Mol Ther. 2017;25:24-43. https://doi.org/10.1016/j.ymthe.2016.10.014.

116. Nakamori M, Gourdon G, Thornton CA. Stabilization of expanded (CTG)*(CAG) repeats by antisense oligonucleotides. Mol Ther 2011;19:2222-2227. https://doi.org/10.1038/mt.2011.191.
117. Siboni RB, Nakamori M, Wagner SD, Struck AJ, Coonrod LA, Harriott SA et al. Actinomycin D specifically reduces expanded CUG repeat RNA in myotonic dystrophy models. Cell Rep 2015;13:2386-2394. https://doi.org/10.1016/j.celrep.2015.11. 028.

118. Witherspoon L, O'Reilly S, Hadwen J, Tasnim N, MacKenzie A, Farooq F. Sodium channel inhibitors reduce DMPK mRNA and protein. Clin Transl Sci 2015;8:298-304. https://doi.org/10.1111/ cts. 12275.

119. Coonrod LA, Nakamori M, Wang W, Carrell S, Hilton CL, Bodner $\mathrm{MJ}$ et al. Reducing levels of toxic RNA with small molecules. ACS Chem Biol 2013;8:2528-2537. https://doi.org/10.1021/ cb400431f.

120. Nakamori M, Taylor K, Mochizuki H, Sobczak K, Takahashi MP. Oral administration of erythromycin decreases RNA toxicity in myotonic dystrophy. Ann Clin Transl Neurol 2016;3:42-54. https://doi.org/10.1002/acn3.271.

121. Hoskins JW, Ofori LO, Chen CZ, Kumar A, Sobczak K, Nakamori $\mathrm{M}$ et al. Lomofungin and dilomofungin: inhibitors of MBNL1-CUG RNA binding with distinct cellular effects. Nucleic Acids Res 2014;42:6591-6602. https://doi.org/10.1093/ nar/gku275.

122. Chen G, Masuda A, Konishi H, Ohkawara B, Ito M, Kinoshita M et al. Phenylbutazone induces expression of MBNL1 and suppresses formation of MBNL1-CUG RNA foci in a mouse model of myotonic dystrophy. Sci Rep 2016;6:25317. https://doi.org/10. 1038/srep25317.

123. Kanadia RN, Shin J, Yuan Y, Beattie SG, Wheeler TM, Thornton $\mathrm{CA}$ et al. Reversal of RNA missplicing and myotonia after muscleblind overexpression in a mouse poly(CUG) model for myotonic dystrophy. Proc Natl Acad Sci U S A. 2006;103: 11748-11753. https://doi.org/10.1073/pnas.0604970103.

124. Wei C, Jones K, Timchenko NA, Timchenko L. GSK3beta is a new therapeutic target for myotonic dystrophy type 1 . Rare Diseases (Austin, Tex). 2013;1:e26555. https://doi.org/10.4161/ rdis.26555.

125. Group F-NBW. BEST (Biomarkers, EndpointS, and other Tools) resource. Silver Spring (MD): Food and Drug Administration (US); 2016.

126. Wojciechowska M, Sobczak K, Kozlowski P, Sedehizadeh S, Wojtkowiak-Szlachcic A, Czubak K et al. Quantitative methods to monitor RNA biomarkers in myotonic dystrophy. Sci Rep 2018;8:5885. https://doi.org/10.1038/s41598-018-24156-x.

127. Rzuczek SG, Colgan LA, Nakai Y, Cameron MD, Furling D, Yasuda R et al. Precise small-molecule recognition of a toxic CUG RNA repeat expansion. Nat Chem Biol 2017;13:188-193. https://doi.org/10.1038/nchembio.2251.

128. Luu LM, Nguyen L, Peng S, Lee J, Lee HY, Wong CH et al. A potent inhibitor of protein sequestration by expanded triplet (CUG) repeats that shows phenotypic improvements in a Drosophila model of myotonic dystrophy. ChemMedChem 2016;11:1428-1435. https://doi.org/10.1002/cmdc.201600081.

129. Warf MB, Nakamori M, Matthys CM, Thornton CA, Berglund JA. Pentamidine reverses the splicing defects associated with myotonic dystrophy. Proc Natl Acad Sci U S A 2009;106: 18551-18556. https://doi.org/10.1073/pnas.0903234106.

130. Nguyen L, Luu LM, Peng S, Serrano JF, Chan HY, Zimmerman SC. Rationally designed small molecules that target both the DNA and RNA causing myotonic dystrophy type 1. J Am Chem Soc 2015;137:14180-14189. https://doi.org/10.1021/jacs.5b09266.

131. Jones K, Wei C, Iakova P, Bugiardini E, Schneider-Gold C, Meola $\mathrm{G}$ et al. GSK3beta mediates muscle pathology in myotonic dystrophy. J Clin Invest 2012;122:4461-4472. https://doi.org/10. 1172/jci64081.

132. Ketley A, Chen CZ, Li X, Arya S, Robinson TE, GranadosRiveron J et al. High-content screening identifies small molecules 
that remove nuclear foci, affect MBNL distribution and CELF1 protein levels via a PKC-independent pathway in myotonic dystrophy cell lines. Hum Mol Genet 2014;23:1551-1562. https:// doi.org/10.1093/hmg/ddt542.

133. Kuyumcu-Martinez NM, Wang GS, Cooper TA. Increased steadystate levels of CUGBP1 in myotonic dystrophy 1 are due to PKCmediated hyperphosphorylation. Mol Cell 2007;28:68-78. https:// doi.org/10.1016/j.molcel.2007.07.027.

134. Brockhoff M, Rion N, Chojnowska K, Wiktorowicz T, Eickhorst $\mathrm{C}$, Erne $\mathrm{B}$ et al. Targeting deregulated AMPK/mTORC1 pathways improves muscle function in myotonic dystrophy type I. J Clin Invest 2017;127:549-563. https://doi.org/10.1172/jci89616.

135. Yadava RS, Foff EP, Yu Q, Gladman JT, Kim YK, Bhatt KS et al. TWEAK/Fn14, a pathway and novel therapeutic target in myotonic dystrophy. Hum Mol Genet 2015;24:2035-2048. https://doi. org/10.1093/hmg/ddu617.

136. Sardone V, Zhou H, Muntoni F, Ferlini A, Falzarano MS. Antisense oligonucleotide-based therapy for neuromuscular disease. Molecules (Basel, Switzerland). 2017;22. https://doi.org/10. 3390/molecules22040563.

137. Wheeler TM, Sobczak K, Lueck JD, Osborne RJ, Lin X, Dirksen RT et al. Reversal of RNA dominance by displacement of protein sequestered on triplet repeat RNA. Science 2009;325:336-339. https://doi.org/10.1126/science.1173110.

138. Wheeler TM, Leger AJ, Pandey SK, MacLeod AR, Nakamori M, Cheng SH et al. Targeting nuclear RNA for in vivo correction of myotonic dystrophy. Nature 2012;488:111-115. https://doi.org/ 10.1038/nature11362.

139. Jauvin D, Chretien J, Pandey SK, Martineau L, Revillod L, Bassez $\mathrm{G}$ et al. Targeting DMPK with antisense oligonucleotide improves muscle strength in myotonic dystrophy type 1 mice. Mol Ther Nucleic Acids 2017;7:465-474. https://doi.org/10.1016/j.omtn. 2017.05.007.

140. Pandey SK, Wheeler TM, Justice SL, Kim A, Younis HS, Gattis D et al. Identification and characterization of modified antisense oligonucleotides targeting DMPK in mice and nonhuman primates for the treatment of myotonic dystrophy type 1. J Pharmacol Exp Ther 2015;355:329-340. https://doi.org/10.1124/jpet.115.226969.

141. Langlois MA, Boniface C, Wang G, Alluin J, Salvaterra PM, Puymirat $\mathrm{J}$ et al. Cytoplasmic and nuclear retained DMPK mRNAs are targets for RNA interference in myotonic dystrophy cells. J Biol Chem 2005;280:16949-16954. https://doi.org/10. 1074/jbc.M501591200.

142. Sobczak K, Wheeler TM, Wang W, Thornton CA. RNA interference targeting CUG repeats in a mouse model of myotonic dystrophy. Mol Ther 2013;21:380-387. https://doi.org/10.1038/mt. 2012.222.

143. Long C, Amoasii L, Bassel-Duby R, Olson EN. Genome editing of monogenic neuromuscular diseases: a systematic review. JAMA Neurol 2016;73:1349-1355. https://doi.org/10.1001/ jamaneurol.2016.3388.

144. Provenzano C, Cappella M, Valaperta R, Cardani R, Meola G, Martelli $\mathrm{F}$ et al. CRISPR/Cas9-mediated deletion of CTG expansions recovers normal phenotype in myogenic cells derived from myotonic dystrophy 1 patients. Mol Ther Nucleic Acids 2017;9: 337-348. https://doi.org/10.1016/j.omtn.2017.10.006.

145. Batra R, Nelles DA, Pirie E, Blue SM, Marina RJ, Wang H et al. Elimination of toxic microsatellite repeat expansion RNA by RnaTargeting Cas9. Cell 2017;170:899.e10-912.e10. https://doi.org/ 10.1016/j.cell.2017.07.010.

146. Gao Y, Guo X, Santostefano K, Wang Y, Reid T, Zeng D et al. Genome therapy of myotonic dystrophy type 1 iPS cells for development of autologous stem cell therapy. Mol Ther. 2016;24: 1378-1387. https://doi.org/10.1038/mt.2016.97.

147. Xia G, Gao Y, Jin S, Subramony SH, Terada N, Ranum LP et al. Genome modification leads to phenotype reversal in human myotonic dystrophy type 1 induced pluripotent stem cell-derived neural stem cells. Stem Cells (Dayton, Ohio). 2015;33:1829-1838. https://doi.org/10.1002/stem.1970. 